\title{
CYP2C9*2 Allele
}

National Cancer Institute

\section{Source}

National Cancer Institute. CYP2C9*2 Allele. NCI Thesaurus. Code C45613.

Human CYP2C9*2 allele is located within $10 \mathrm{q} 24$ and is approximately $33 \mathrm{~kb}$ in length. This allele, a variant form of the CYP2C9 wild-type allele, encodes cytochrome P450 2C9*2 protein. The CYP2C9*2 allele exhibits a clinically-relevant SNP (c.430C $>$ T) in exon 3 that results in a R144C coding change. This alteration in protein sequence decreases the enzymatic activity of the cytochrome P450 2C9*2 protein. 